schizophrenic blood, have proved equivocal. Dr. Kety affirmed that it was most difficult to plan experiments to compare psychotics with normal controls. To obtain proper controls was a considerable feat in itself, and most research had been carried out on patients in institutions who had, among other things, been on an unusual diet. This latter consideration often accounted for reports of the atypical urinary constituents of mental patients. The subconscious desire on the part of the investigator to eliminate conflicting data had also to be overcome. There was considerable discussion after Dr. Kety's paper on the problems inherent in undertaking bio- chemical studies in mental disease, and one or two speakers put in a plea for investigators to publish negative findings, if only to eliminate duplication of effort.

Altogether the Strasbourg conference was a stimulating experience and thanks are due to the organizing committee for the first-class presentation. All members of the Symposium are indebted also to Prof. Mandel and the Comite de Patronage for the hospitality shown in Strasbourg, and no one will easily forget the many social events organized for the delight of members, especislly the outing to Obernai.
G. B. ANSELI

\title{
HUMAN AND ANIMAL MYCOLOGY
}

$\mathrm{T}$ HE International Society for Human and Animal Mycology met in Lisbon during September 5-10. The meeting, the first since the Society was founded in Paris in 1954, was held by permission of the President and General Secretary of the Sixth International Congresses on Tropical Medicine and Malaria. It was attended by more than sixty members of the Society, and twenty-one countries, including the U.S.S.R., Japan, the United States, Brazil, South Africa and Australia, were represented.

Three of the sessions on tropical medicine were devoted to mycotic infections, and these covered the clinical and epidemiological aspects of mycoses, the ecology and saprophytic occurrence of pathogenic fungi and the biochemistry and physiology of pathogenic fungi. In addition, the Society held two business meetings and three paper-reading sessions. Altogether there were more than forty communications, and ample time was allowed for discussion.

In a brief report of the proceedings it is difficult to select, from the many papers presented, those most worthy of note. However, no account would be complete without reference to the contributions on the ecology of pathogenic fungi. Dr. C. W. Emmons (United States) pointed out that, for many of the mycoses, we know that saprophytic growths provide the inocula from which man and animals are infected, and that all epidemiological evidence suggests the probability of saprophytic sources of inocula for a number of other mycoses. He suggested that attempts to isolate the fungi from soil of areas where the specific mycoses are endemic, and a more careful comparison of certain rare pathogens with fungi already described in the literature of general mycology may well increase or complete the list of pathogens with known saprophytic sources. Dr. Emmons said that most of the pathogens of man have a wide geographical distribution and their local distribution is dependent upon ecological factors only partially recognized.

The results of a four-year study of Coccidioides immitis in the soil of the South-West Joaquin Valley of California were given by Dr. Egeberg (United States). He discussed the ecological and epidemiological significance of the recovery-rate of the fungus being highest in surface soil three to four weeks after the end of the rainy season, most consistent from the walls of animal burrows, and lowest from the surface towards the end of the dry season when the incidence of the disease is at its highest.

Dr. P. Abbot (Britain), in his consideration of mycetoma, noted that for this disease the incidence is apparently correlated with climatic conditions rather than with specific soil types or other factors. The recovery of the dermatophytes Microsporum canis, $M$. gypseum and the non-pathogenic keratinophilic fungi Trichophyton terrestre, which is a new species, and Keratinomyces ajelloi from the soil of Australia and New Guinea was discussed by Dr. E. B. Durie (Australia), who also reviewed previous work on the ecology of dermatophytes. In his consideration of the mouth as a reservoir of pathogenic fungi, Dr. G. C. Ainsworth (Britain) pointed out that of the many and diverse fungi recorded from the mouth, most are 'contaminants' and only a small number may be considered as 'inhabitants'. Some of the 'inhabitants' appear to provide a reservoir of infection for such endogenous diseases as candidiasis and actinomycosis. A single isolation of Cryptococcus neoformans from a healthy horse, during his investigations into the intestinal yeast flora of man and domestic animals, was reported by Dr. N. Van Uden (Portugal). This pathogenic yeast has been shown in the United States to be frequently associated with pigeon droppings, and Dr. K. Ishida (Japan) reported similar findings in Tokyo.

Histoplasmosis was the subject of a number of contributions. The first occurrence of this disease in Japan was reported by Dr. H. Yamato, and a paper on the distribution of histoplasmosis in South Africa was given by Dr. H. I. Lurie. Dr. E. Drouhet (France) and Dr. J. Schwarz (United States) both reported that in culture there is no apparent difference between Histoplasma duboisii, first described by Vanbreuseghem in 1952, and $H$. capsulatum. However, the geographical distribution and the clinical and pathological aspects of African histoplasmosis caused by $H$. duboisii differ considerably from the classic form of the disease caused by $\boldsymbol{H}$. capsulatum, and it was generally agreed that for the present it is useful to consider them separately.

In an interesting communication Dr. A. C. Batista (Brazil) stated that from the results of investigations carried out in Brazil it is clear that fungi such as Candida and Torulopsis may be a primary cause of cholecystitis. Dr. C. S. da Silva Lacaz (Brazil) gave an excellent account of the clinical and epidemiological 
aspects of the serious mycoses in South America and also showed a most interesting film which he had made on South American blastomycosis.

The importance of therapy was not overlooked. Dr. M. Muftic (Iraq) reported on trials of mycostatin (nystatin) derivatives used intravenously and intramuscularly for the treatment of coccidioidomycosis, and Dr. J. C. Gentles (Britain) gave an account of experimental work which demonstrated the efficacy of oral treatment with the antibiotic griseofulvin for dermatophyte infections.

The use of serological tests for identification and classification of fungi were considered by Dr. H. Seeliger (Germany) and Dr. T. Tsuchiya (Japan).

The social side of the Congresses in tropical medicine and malaria, in which Society members took part, was well organized, and it would be difficult to speak too highly of the hospitality of our Portuguese hosts. The impressive opening ceremony was held in the National Assembly (Palace of São Bento) under the presidency of His Excellency the President of the Republic of Portugal. Evening visits were arranged to places of interest in Lisbon, such as the estufa fria (cool greenhouse) in the Parque Eduardo VII and to palaces and gardens in the neighbouring towns of Sintra and Queluz. On the first Sunday there was an excursion to the University of Coimbra.

During the two business meeetings of the Society it was announced that there are now more than two hundred members, and that it would shortly be possible to begin publication of a journal devoted to hurnan and animal mycology. It was agreed that membership of the Society should be open to all interested in medical and veterinary mycology. The date for the next meeting is to be decided by the executive committee: President, J. E. Mackinnon (Uruguay); Vice-Presidents, G. C. Ainsworth (Britain); C. W. Emmons (U.S.A.) ; P. Negroni (Argentine) ; G. Segretain (France) ; General Secretary, R. Vanbreuseghem (Institut de Médecine Tropicale, 155 rue Nationale, Antwerp). J. C. GentLes

\section{STUDENT APPRENTICESHIP IN ELECTRICAL ENGINEERING}

GTUDENT apprenticeship is the subject of a $\$$ report* published recently by the Institution of Electrical Engineers. The report is the work of a joint committee, under the chairmanship of Sir Willis Jackson, appointed by the Council of the Institution in consultation with the Council of the British Electrical and Allied Manufacturers Association, the Radio Industry Council and other interested bodies.

It is stated in the foreword that the report aims to do two things : first, to explain to teachers, senior pupils and parents the scope of the educational requirements and the training envisaged in student apprenticeship for electrical engineering; and secondly, to give guidance to those responsible for the education and training of student apprentices as to the structure and content of academic courses and practical training.

Graduate apprenticeship and student apprenticeship are the two main avenues leading to professional qualification in electrical engineering in Britain. A university graduate, on completion of his three- or four-year full-time course of study, will normally undertake a two-year apprenticeship with a manufacturing or operating organization. The student apprentice, on the other hand, enters industry from school and pursues academic study more or less in parallel with his practical training throughout a period of five or more years. Study and practical experience can be interleaved in a wide variety of ways, but one pattern which has evolved and which shows increasing practical importance is that of the sandwich course of five years duration, in which four six-month periods of full-time study are interposed between five equal periods of practical experience in industry. Recruitment to a scheme of student apprenticeship should take place normally at about the age of eighteen, the candidate having pursued sixth-form work at school and having obtained passes in mathematics

* The Education and Training of Student Apprentices in Electrical Engineering: a Report of the Joint Committee on Practical Training in the Electrical Engineering Industry. Pp. 26. (London: Institution of Electrical Engineers, 1958.) $2 s$. and physics at Advanced Level together with five or' more passes in suitable subjects at Ordinary Level of the General Certificate of Education. There is, however, provision for entry from the National Certificate course, the requirement being a 'good' Ordinary National Certificate. Thus, the boy who has left school early and has embarked upon craft or technician training is not debarred from entering upon the professional course provided that his studies have shown sufficient promise.

The successful completion of a sandwich course will normally qualify for a recognized award such as that of the recently established Dip.Tech.(Eng.) or of a. college diploma. It must be emphasized that a distinctive feature of the sandwich course is the association of the industrial experience with the academic study as an integral part of the course, it being a requirement that the student should have completed his practical training satisfactorily as well as his examinations before the award is granted.

Sandwich courses are normally 'industry based, that is to say, the student is recruited by an indus. trial organization as a student apprentice and the firm takes responsibility for the complete planning of his industrial experience throughout the five sixmonth periods which he will spend in the works. This arrangement works well with large organizations within which the whole range of experience required by the apprentice can be obtained. The position of smaller firms may be less satisfactory, as an individual concern may be able to provide excellent training covering a part of the requirement but be completely deficient in respect of other portions. This difficulty is being met by group training schemes in which a number of concerns co-operate in providing full professional training facilities, and the group, in fact, accepts a collective responsibility towards the apprentices of the individual concern.

As an alternative to the 'industry based' sandwich course there is provision for 'college based' courses in which the college accepts the student and nakes suitable arrangements with one or more firms to 